\title{
Effects of Landscape Attributes on Campuses Bird Species Richness and Diversity, Implications for Eco-Friendly Urban Planning
}

\author{
Yong Zhang ${ }^{1, *} \mathbb{D}$, Chao Jiang ${ }^{1} \oplus$, Sheng Chen ${ }^{1}$, Yuanyuan Zhang ${ }^{2}$, Hui Shi ${ }^{1}$, Bin Chen ${ }^{1}$ and Lingfeng Mao ${ }^{1}$ \\ 1 Co-Innovation Center for Sustainable Forestry in Southern China, College of Biology and the Environment, \\ Nanjing Forestry University, Nanjing 210037, China; jych@njfu.edu.cn (C.J.); neo0306@njfu.edu.cn (S.C.); \\ shihui@njfu.edu.cn (H.S.); bin.chen@njfu.edu.cn (B.C.); maolingfeng2008@163.com (L.M.) \\ 2 School of Life Sciences, Nanjing University, Nanjing 210023, China; yyuanzhang@smail.nju.edu.cn \\ * Correspondence: yong.zhang@nfu.edu.cn
}

Citation: Zhang, Y.; Jiang, C.; Chen, S.; Zhang, Y.; Shi, H.; Chen, B.; Mao, L. Effects of Landscape Attributes on Campuses Bird Species Richness and Diversity, Implications for Eco-Friendly Urban Planning. Sustainability 2021, 13, 5558. https:// doi.org/10.3390/su13105558

Academic Editor: Vilém Pechanec

Received: 22 March 2021

Accepted: 7 May 2021

Published: 17 May 2021

Publisher's Note: MDPI stays neutral with regard to jurisdictional claims in published maps and institutional affiliations.

Copyright: ( $\odot 2021$ by the authors Licensee MDPI, Basel, Switzerland. This article is an open access article distributed under the terms and conditions of the Creative Commons Attribution (CC BY) license (https:// creativecommons.org/licenses/by/ $4.0 /)$.

\begin{abstract}
Landscape changes due to urban expansion may severely influence urban biodiversity through direct and indirect effects. Hence, a comprehensive understanding of the urban expansion effects on species diversity is essential for conservation biologists, urban planners, and policymakers to help design more practical and effective conservation strategies. Here, based on monthly bird survey data of 12 university campuses distributed in the center and the Xianlin university town of Nanjing city, we first compared the differences of the campuses bird species richness, ShannonWiener, and Simpson indices. Then, we analyzed the effects of a variety of landscape attributes on the campuses bird species richness. Unlike other studies, we also constructed a $2 \mathrm{~km}$ buffer area surrounding each campus and analyzed the effects of the landscape attributes of the buffer area on species richness. We found that bird species richness was higher in the campus of Xianlin compared to those in the center. Landscape attributes played an important role on bird species richness, especially for the determinants in the buffer area. Specifically, species richness, Shannon-Wiener, and Simpson indices increased with the increasing area of water and green space both within the campus and the buffer area. Not surprisingly, bird species richness and diversity were more affected by fragmentation of the buffer area, increasing with the aggregation index and decreasing with the splitting index. Our study emphasized that landscape attributes of both campuses and buffer areas determined bird species richness and diversity, offering several practical implications for urban biodiversity maintenance and eco-friendly urban planning.
\end{abstract}

Keywords: urbanization; biodiversity; landscape attributes; buffer area; urban planning

\section{Introduction}

Global biodiversity loss has been drawing increasing concerns for ecologists and conservation biologists [1]. Among them, the anthropogenic factor is one of the main drives for habitat degradation and habitat loss that leads to rapid biodiversity loss [2]. The urban area especially, dominated by human beings, has suffered heavy biodiversity loss under the context of fast urbanization [3]. Urban expansion may severely influence urban biodiversity through direct (e.g., remarkable landscape changing) and indirect effects (e.g., resource consumption) [4]. Hence, a comprehensive understanding of the urban expansion effects on species diversity is essential for conservation biologists, urban planners, and policymakers to minimize the impact of urban development on biodiversity and help design more practical and effective conservation strategies [5].

Birds are commonly used as an important environmental indictor and surrogate for other animals, as they are widely distributed and easily observed [6]. A strong and globally consistent reduction in their taxonomic diversity was detected in urban areas [3]. Previous studies showed that urban landscape attributes (e.g., land cover type and fragmentation) 
play an important role on urban bird species richness. Paker et al. [7] found that bird species richness in urban areas was often higher in areas with a higher shrub species richness, while trees and lawns only attracted aliens and urban exploiters, indicating a positive relationship between green space areas and bird species richness. A study in Europe suggested that open green space, woody vegetation, and impervious surfaces favored bird species richness in the city [8]. Contiguous urban green space accommodated more birds than fragmented small green space patches, suggesting that habitat fragmentation may have a negative effect on urban bird biodiversity [9]. In contrast, there are also studies showing that habitat fragmentation had little effects on urban bird diversity [10].

Despite that, urban bird biodiversity loss has received increasing attention; most studies to date are mainly carried out in urban parks (but see Zhang et al. 2018 [11]). In China, university campuses are one of the important components of urban ecosystems. The development of higher education in China has brought the construction boom of new campuses [12]. In comparison to other urban habitats, university campuses are generally well planted and eco-friendly, hosting many urban bird species. In addition, almost all university campuses in China are enclosed with a clear boundary, offering a good opportunity to study the effects of landscape attributes on bird species richness. A large scale analyses showed that altitudinal range and climate factors were the main factors affecting campus bird species richness [11]. However, to date, studies about landscape attribute effects on campus bird species richness are still lacking.

More importantly, the landscape type of the surrounding buffer area may also affect bird species richness and diversity. Studies suggested that the type of landscape (e.g., streets within the urban village) may influence accessibility and the urban interface, which potentially affects urban biodiversity by increasing human disturbances $[13,14]$. However, in comparison to other ecosystems, influences of the surrounding environments on urban bird species richness are still poorly documented, inhibiting a comprehensive understanding of biodiversity patterns across urban environments.

In this study, based on monthly bird survey data of 12 university campuses distributed in the center (hereafter center) and the Xianlin university town (hereafter Xianlin) of Nanjing city, we first compared the differences of the campuses bird species richness, Shannon-Wiener, and Simpson indices. Then, we analyzed the effects of a variety of landscape attributes on the campuses bird species richness. Unlike other studies which only focused on the determinants within the campus, we also constructed a $2 \mathrm{~km}$ buffer area surrounding each campus and analyzed the effects of the landscape attributes of the buffer area on species richness, as surrounding environments may also effectively affect campus bird species richness. Specifically, we test our hypothesis as follows: (1) Species richness and diversity are higher in the campus of Xianlin because of fewer disturbances and more vegetation coverage. (2) Species richness and diversity will increase with the increasing area of urban green spaces but decrease with increasing habitat fragmentation. We made a set of priori predictions for selected landscape attributes (see details in Table 1). 
Table 1. Selected landscape attributes, their abbreviations, and predicted effects $\left(\mathrm{H}_{0}\right)$ on campus birds species richness, Shannon-Wiener, and Simpson indices. +: positive effect, -: negative effect.

\begin{tabular}{|c|c|c|}
\hline Landscape Attributes & Abbreviations & $\mathbf{H}_{0}$ \\
\hline Total area of the campus & $\mathrm{Ta}$ & + \\
\hline Woody vegetation area including trees and shrubs & Forest & + \\
\hline Grass area & Grass & + \\
\hline Building area & Building & - \\
\hline Impervious surface area including parking areas, playgrounds, and squares & Isurf & - \\
\hline Water body area including ponds, rivers, and urban lakes & Water & + \\
\hline Woody vegetation area within $2 \mathrm{~km}$ buffer area & Forest2 & + \\
\hline Grass area within $2 \mathrm{~km}$ buffer area & Grass2 & + \\
\hline Building area within $2 \mathrm{~km}$ buffer area & Build2 & - \\
\hline Impervious surface area within $2 \mathrm{~km}$ buffer area & Isurf2 & - \\
\hline Water body area within $2 \mathrm{~km}$ buffer area & Water2 & + \\
\hline Patch density & $\mathrm{Pd}$ & - \\
\hline Largest patch index & Lpi & + \\
\hline Edge density & Ed & - \\
\hline Mean patch area & Marea & + \\
\hline Proportion of like adjacency & Pladj & + \\
\hline Connectance index & Connect & + \\
\hline Splitting index & Split & - \\
\hline Aggregation index & $\mathrm{Ai}$ & + \\
\hline Patch density within $2 \mathrm{~km}$ buffer area & $\mathrm{Pd} 2$ & - \\
\hline Largest patch index within $2 \mathrm{~km}$ buffer area & Lpi2 & + \\
\hline Edge density within $2 \mathrm{~km}$ buffer area & Ed2 & - \\
\hline Mean patch area within $2 \mathrm{~km}$ buffer area & Marea2 & + \\
\hline Proportion of like adjacency within $2 \mathrm{~km}$ buffer area & Pladj2 & + \\
\hline Connectance index within $2 \mathrm{~km}$ buffer area & Connect2 & + \\
\hline Splitting index within $2 \mathrm{~km}$ buffer area & Split2 & - \\
\hline Aggregation index within $2 \mathrm{~km}$ buffer area & Ai2 & + \\
\hline
\end{tabular}

\section{Materials and Methods}

\subsection{Study Area}

Nanjing $\left(118^{\circ} 46^{\prime} \mathrm{E}, 32^{\circ} 02^{\prime} \mathrm{N}\right)$, the capital city of Jiangsu province, is located in the lower Yangtze River reach (Figure 1). The climate belongs to the northern edge of the northern subtropical climatic zone, with the mean annual temperature of $15.4{ }^{\circ} \mathrm{C}$ and mean annual precipitation of $1033 \mathrm{~mm}$. It is one of the biggest cities in eastern China with a population size of ca. 8.5 million. With more than 50 universities, Nanjing is also famous for its reputation of higher education in China. In the past, most of the university campuses were located in/near the center of Nanjing. However, during the last two decades, because of the fast urbanization and the higher education acceleration, the Xianlin university towna new developing suburban area lying in the eastern part of Nanjing-started construction in 2002. To date, there are around 12 universities in Xianlin. 


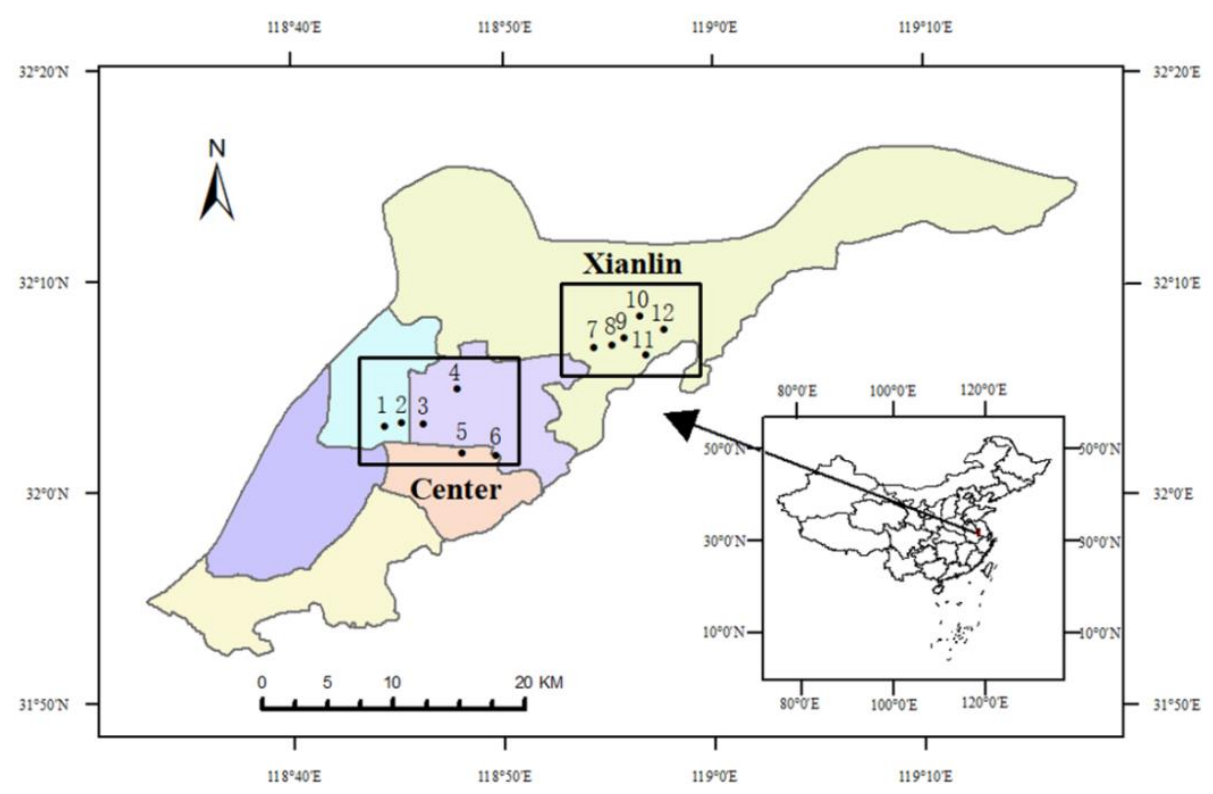

Figure 1. Location of Nanjing City, China (inset bottom right) and positions of the selected 12 campuses in the center of Nanjing and Xianlin university town. 1: Nanjing Normal University (Shuiyuan Campus); 2: Nanjing University (Gulou Campus); 3: Southeast University (Sipailou Campus); 4: Nanjing Forestry University; 5: Nanjing University of Aeronautics and Astronautics (Minggugong Campus); 6: Nanjing Agriculture University (Weigang Campus); 7: Nanjing Normal University (Xianlin Campus); 8; Nanjing University of Finance \& Economics (Xianlin Campus); 9: Nanjing University of Posts and Telecommunications (Xinlin Campus); 10: Nanjing Vocational College of Information Technology (Xianlin Campus); 11: Nanjing University of Chinese Medicine (Xianlin Campus); 12: Nanjing University (Xianlin Campus).

\subsection{Bird Census}

Six university campuses located in the center and Xianlin areas were selected, respectively (see details in Figure 1). A monthly bird census was conducted for each campus using the line transect method [15], from January to December, 2019. Within each campus, two survey transects covering a variety of habitat types were set up. The length of transects ranged from 1 to $2 \mathrm{~km}$, depending on campus size. Surveys were carried out between 07:00 and 10:00 in the morning and from 16:00 to 19:00 in the afternoon on days without rain, snow, or strong winds. During the surveys, the observers walked along transects with a speed of approximately $3 \mathrm{~km}$ per hour. Birds were observed through hearing, unaided eyes, or using a $10 \times 40$ binocular within $50 \mathrm{~m}$ of each transect. Bird species and their numbers were recorded for each transect separately during the surveys.

\subsection{Land Cover Types Classification and Landscape Attributes}

Google Earth satellite imagery (imagery taken in November 2018) with a $2 \mathrm{~km}$ buffer area (hereafter buffer area) surrounding each campus boundary was used to classify the land cover types in Arcgis 10.3. Based on the imagery data and field surveys, the landscape was divided into five types: buildings; grass, such as lawns; woody vegetation, including trees and shrubs; impervious surfaces, such as parking areas, playgrounds, and squares; and water bodies, including ponds, rivers, and urban lakes. After that, we calculated the area of each land cover type for each campus and its buffer area, respectively. As acquiring high resolution satellite imagery is difficult, we were only able to access imagery taken in November 2018, which may bias our analyses as vegetation phenology differs among seasons. However, according to our observations, most of the vegetation within and surrounding the university campuses are evergreen plants, suggesting little effect when classifying habitat types and calculated area of different habitat types. 
We further calculated landscape fragmentation indices in both patch level and landscape level using Fragstat 4.2. Patch density (Pd), largest patch index (Lpi), edge density (Ed), mean patch area (Marea), proportion of like adjacency (Pladj), connectance index (Connect), splitting index (Split), and aggregation index (AI) were selected.

\subsection{Statistical Analysis}

We divided our field surveys into four seasons: spring (March-May), summer (JuneAugust), autumn (September-November), and winter (December-February) and the survey data were lumped for each season. After that, we calculated species richness (number of species) for each campus. In addition, to obtain a better understanding of the effects of different attributes on urban bird diversity, we calculated both Shannon-Wiener $(\mathrm{H})$ and Simpson diversity (D) indices for each campus in order to weight both rare and common species, using the following equations, respectively:

$$
\begin{gathered}
H=\sum_{i=0}^{N} P_{i} \ln P_{i} \\
D=1-\sum_{i=0}^{N} P_{i}^{2}
\end{gathered}
$$

where $P_{i}$ is the proportion of bird number of species, $i$ is the total bird abundance within each campus.

We first compared if bird species richness, Shannon-Wiener, and Simpson indices across campuses significantly differed between the center and Xianlin and if they also differed among seasons. This was conducted using general mixed linear models (GLMM), following a Tukey post hoc test. In the models, area, season, and their interaction term were included as fixed factors with the campus as the random factor. Species richness was square-root-transformed before the analyses.

To examine the effects of different landscape attributes on campus bird species richness, we further lumped bird survey data for the whole year of each surveyed campus and calculated species richness, Shannon-Wiener, and Simpson indices, respectively. In total, 27 landscape attributes were selected to test for the effects of area of different habitat types and fragmentation on bird species richness and diversity (Table 1). Prior to analyses, data exploration indicated high multicollinearity among predictor variables (i.e., Spearman rank coefficient $r>0.6$ ); thus, following the standard process to remove variables may have biased our analyses as a lot of the useful information would be neglected. Instead, we applied stepwise linear regressions to test for the effects of these variables on species richness and diversity in turn. Selected variables, their abbreviations, and predicted effects (H0) are shown in Table 1, and the research design is shown in Figure 2. Statistical analyses were conducted in $\mathrm{R}$ 4.0.3.

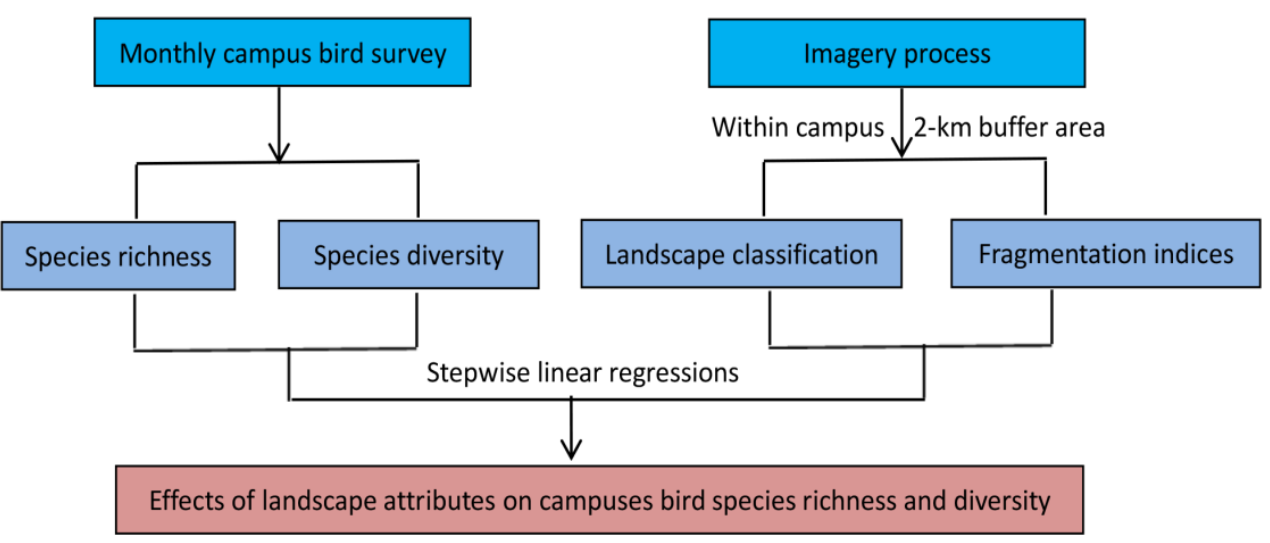

Figure 2. A framework graph to show research design. 


\section{Results}

In total, 67 bird species belonging to 31 families were found throughout the year 2019 (supporting information, Table S1). Both season and area factors significantly affected species richness. In general, species richness and the Shannon-Wiener index were significantly higher in Xianlin than those in the center, however, the extent of the differences were dependent on specific seasons as indicated by the significant area $\times$ season interaction effect (Table 2, Figures 3 and 4). That is, the significant differences only occurred in spring and summer but not in autumn or winter (Figures 3 and 4). Although the Simpson index was also affected by area and season, there was no significant area $\times$ season interaction effect (Table 2, Figure 5).

Table 2. Effects of area, season, and their interaction term on campus bird species richness, ShannonWiener, and Simpson indices.

\begin{tabular}{ccccccc}
\hline & \multicolumn{2}{c}{ Area } & \multicolumn{2}{c}{ Season } & \multicolumn{2}{c}{ Area $\times$ Season } \\
\cline { 2 - 7 } & $\boldsymbol{F}$ & $\boldsymbol{p}$ & $\boldsymbol{F}$ & $\boldsymbol{p}$ & $\boldsymbol{F}$ & $\boldsymbol{p}$ \\
\hline Species richness & 20.299 & $0.001^{* * *}$ & 4.461 & $0.010^{*}$ & 8.864 & $<0.001^{* * *}$ \\
Shannon-Wiener index & 11.376 & $0.007^{* *}$ & 4.090 & $0.015^{*}$ & 4.538 & $0.010^{*}$ \\
Simpson index & 5.827 & $0.036^{*}$ & 3.049 & $0.044^{*}$ & 0.973 & 0.418 \\
\hline
\end{tabular}

$F$-factor score, $p$ - significant level at ${ }^{*} p<0.05,{ }^{* *} p<0.01$, $^{* * *} p<0.001$.

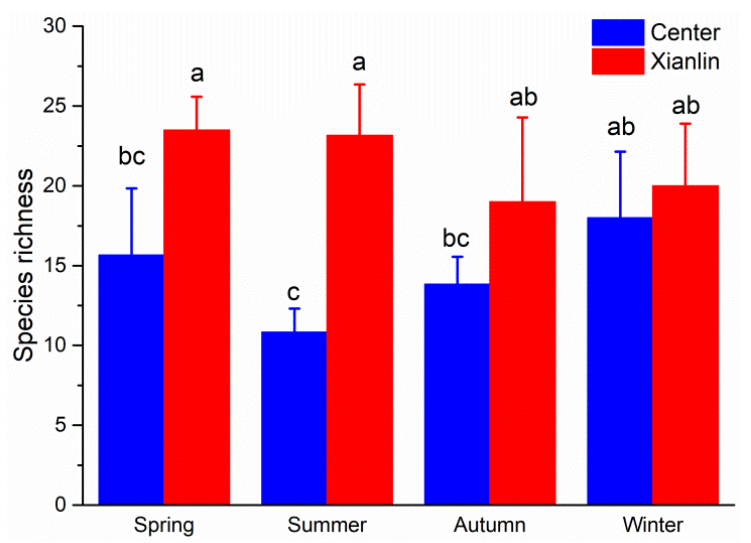

Figure 3. Comparing the seasonal campus bird species richness in the center (center) of Nanjing and Xianlin university town (Xianlin). Error bars show Standard deviation. Different letters in superscript on the bar graph indicate significance at 0.05 level by Tukey's post hoc test.

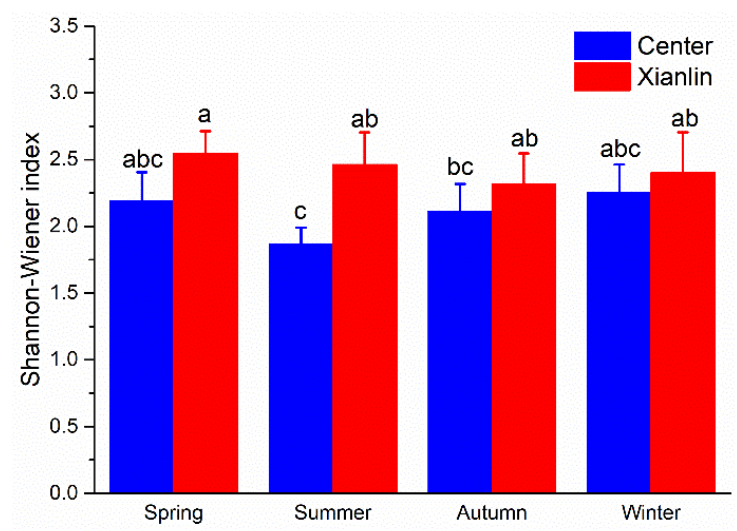

Figure 4. Comparing the seasonal campus birds Shannon-Wiener index in the center (center) of Nanjing and Xianlin university town (Xianlin). Error bars show Standard deviation. Different letters in superscript on the bar graph indicate significance at 0.05 level by Tukey's post hoc test. 


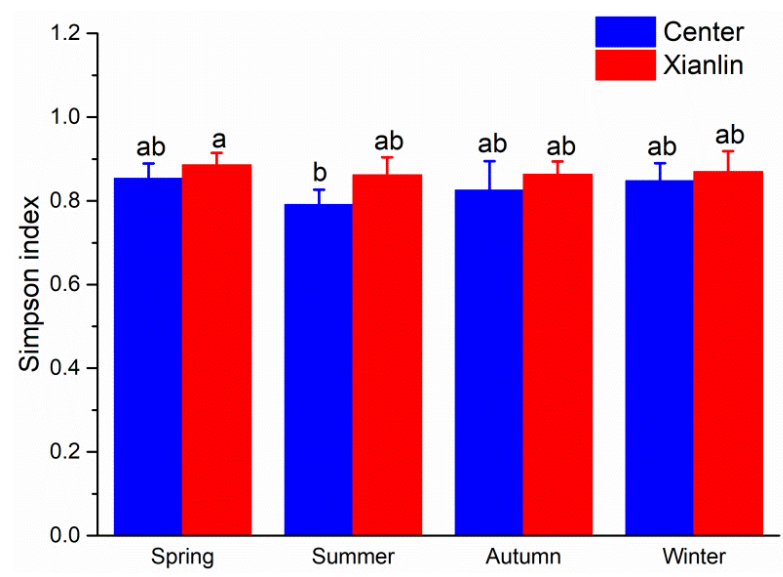

Figure 5. Comparing the seasonal campus birds Simpson index in the center (center) of Nanjing and Xianlin university town (Xianlin). Error bars show Standard deviation. Different letters in superscript on the bar graph indicate significance at 0.05 level by Tukey's post hoc test.

The results of linear regression models showed that a variety of landscape attributes had significant effects on bird species richness. The bird species richness is based on the survey data throughout the year. The number of species increased with the increasing areas of water, impervious surfaces, grass of the campus, and grass and forest areas of the buffer area. The building area within the buffer zone had a negative effect on species richness (Table 3). In terms of fragmentation indices, aggregation index, and proportion of like adjacency within the campus and the buffer area, plus mean patch area in the buffer area positively correlated with bird species richness. Campus edge density and patch density of the buffer area negatively affected bird species richness (Table 3).

Table 3. Results of stepwise regression models showing the effects of landscape attributes on campus bird species richness and diversity. se $=$ standard error of the regression coefficient; $t$ value, $p$ value with significant level at 0.05 , and adjusted R-square. For the variables' abbreviations, see Table 1.

\begin{tabular}{|c|c|c|c|c|c|c|c|}
\hline Indices & $\begin{array}{l}\text { Variables } \\
\text { Categories }\end{array}$ & Variables & $\begin{array}{l}\text { Regression } \\
\text { Coefficient }\end{array}$ & se & $t$ & $p$ & $\begin{array}{l}\text { Adjusted } \\
\text { R-Square }\end{array}$ \\
\hline \multirow{14}{*}{ Species richness } & \multirow{8}{*}{ Habitat area } & Water & 6.12 & 1.933 & 3.166 & 0.010 & 0.45 \\
\hline & & Isurf & 3.16 & 1.133 & 2.791 & 0.019 & 0.38 \\
\hline & & Grass & 2.71 & 0.686 & 3.95 & 0.003 & 0.57 \\
\hline & & Grass2 & 0.29 & 0.077 & 3.819 & 0.003 & 0.55 \\
\hline & & $\mathrm{Ta}$ & 0.22 & 0.095 & 2.277 & 0.046 & 0.28 \\
\hline & & Forest2 & 0.05 & 0.019 & 2.802 & 0.019 & 0.38 \\
\hline & & Build2 & -0.13 & 0.041 & -3.191 & 0.010 & 0.46 \\
\hline & & Marea2 & 1.37 & 0.409 & 3.343 & 0.007 & 0.48 \\
\hline & \multirow{6}{*}{ Fragmentation index } & $\mathrm{Ai}$ & 0.05 & 0.017 & 2.876 & 0.017 & 0.4 \\
\hline & & Pladj & 0.04 & 0.015 & 2.859 & 0.017 & 0.39 \\
\hline & & $\mathrm{Ai} 2$ & 0.03 & 0.012 & 2.83 & 0.018 & 0.39 \\
\hline & & Pladj2 & 0.03 & 0.012 & 2.806 & 0.019 & 0.38 \\
\hline & & $\mathrm{Pd} 2$ & -0.00 & 0.00 & -3.185 & 0.010 & 0.45 \\
\hline & & $\mathrm{Ed}$ & -0.00 & 0.000 & -2.268 & 0.047 & 0.27 \\
\hline \multirow{5}{*}{ Shannon-Wiener Index } & \multirow{3}{*}{ Habitat area } & Water & 5.48 & 2.166 & 2.53 & 0.030 & 0.33 \\
\hline & & Grass2 & 0.22 & 0.010 & 2.201 & 0.050 & 0.26 \\
\hline & & Marea2 & 1.09 & 0.494 & 2.214 & 0.050 & 0.26 \\
\hline & \multirow{2}{*}{ Fragmentation index } & Pladj2 & 0.03 & 0.013 & 2.305 & 0.044 & 0.28 \\
\hline & & $\mathrm{Ai} 2$ & 0.03 & 0.013 & 2.279 & 0.046 & 0.28 \\
\hline \multirow{2}{*}{ Simpson index } & \multirow{2}{*}{ Fragmentation index } & Ai2 & 0.01 & 0.002 & 2.184 & 0.054 & 0.26 \\
\hline & & Split2 & -0.00 & 0.000 & -2.727 & 0.021 & 0.37 \\
\hline
\end{tabular}


The Shannon-Wiener and Simpson indices were more affected by landscape attributes of the buffer area. Grass area, mean patch size, aggregation index, and proportion of like adjacency of the buffer area positively correlated with the Shannon-Wiener index. In addition, campus water area had a positive effect on the Shannon-Wiener index (Table 3). Fragmentation of the buffer area also significantly affected the Simpson diversity index, which was positively affected by the aggregation index but negatively affected by the splitting index (Table 3).

\section{Discussion}

In this study, using monthly bird survey data, we investigated the effects of landscape attributes on campus bird species richness in Nanjing. We found that bird species richness was higher in the campus of Xianlin compared to those in the center. Landscape attributes played an important role on bird species richness, especially for the determinants in the buffer area. To our knowledge, this is the first time the landscape attributes of a buffer area were included in such analyses, highlighting the importance of the buffer area for biodiversity maintenance.

In line with our prediction, our results showed that bird species richness and diversity were higher in campuses of Xianlin than those in the center. Urban centers are often highly urbanized, with numerous high buildings and much more traffic noise but generally fewer green spaces, which is not preferable to birds [16]. Former studies suggested that the distance to the urban center positively correlated with bird species richness [10,17]. In our study area, although Xianlin also accommodates a large human population, it is a relatively new suburban area with higher greenness and larger waterbodies, favoring urban bird species. Seasonal differences were also detected. Differences in bird species richness and the Shannon-Wiener diversity between areas were significant in spring and summer (Table 2), indicating the importance of vegetation phenology on governing the urban bird community $[18,19]$.

Both landscape attributes of campuses and their buffer areas affected bird species richness, Shannon-Wiener, or/and Simpson indices. Consistent with our hypotheses, the area of the campuses, water bodies, and green spaces (both within campus and the buffer area) positively affected species richness and diversity (Table 3). The species-area relationship theory [20] predicts that species richness will increase with an increasing habitat area. Our results are also in accordance with several studies on the effects of urban green spaces conducted in urban parks [10,21,22]. Furthermore, our results showed that the area of grass and forest in the buffer area strongly correlated with campus bird species richness and the Shannon-Wiener index (Table 3). Surrounding environments with a higher vegetation cover were proved to be able to support more bird species in urban parks [23]. Species richness also decreased with increasing road cover in the surrounding landscape [24]. The surrounding landscape with more vegetation cover would provide compensation habitats for birds beyond campuses' limits and act as a movement corridor, which might explain the positive effects on the campus bird species richness.

Although the effects of the building area in the surrounding landscape on bird species occurrence tend to be taxon dependent $[25,26]$, a negative effect was detected on species diversity in our study (Table 3). Buildings may offer nesting habitats for cavity nesters [25], however, a larger cover of buildings in the surrounding landscape is not eco-friendly and not preferable for native and insectivorous species [27]. Conversely, parks located in the nearby landscape with lower building density usually harbor a higher bird diversity [28].

As predicted, landscape fragmentation of both the campus and the buffer area influenced bird species richness and diversity (Table 3). Significant positive influences of mean patch area, aggregation index, and proportion of like adjacency were observed. Campuses with a larger total area, mean patch area, aggregation index, and proportion of like adjacency attracted more species of birds. In addition, bird species richness was negatively affected by patch density, edge density, and splitting index. Habitat fragmentation has long been considered to negatively affect biodiversity [29]. Fragmentation by road construction 
strongly decreased bird species richness and abundance [30]. Habitat fragmentation may reduce the proportion of patches that are large enough to support stable or productive populations [31]. Bird survival and population growth rate were also lower in small, fragmented areas [32].

Unlike previous studies, we also demonstrated that habitat fragmentation of the surrounding landscape strongly correlated with the campuses bird species richness and diversity. Following our predictions, indictors such as mean patch area, aggregation index, and proportion of like adjacency had positive effects, while edge density and splitting index had opposite effects. As discussed above, a surrounding landscape with larger vegetation cover and better connected habitats would maintain higher species abundance and diversity $[33,34]$, compensating for the limitation of campus supplements.

\section{Conclusions}

In the Anthropocene, human activities have dramatically altered the Earth's surface, of which urbanization is one of the fundamental processes [35]. Urban biodiversity was frequently documented to be decreasing with increasing urbanization level [36]. To date, urban green spaces have received much more attention in biodiversity studies. Unfortunately, few research efforts were invested on university campuses, although they are also good shelters for urban bird species. In this study, we found that the area of green space both within campus and the surrounding $2 \mathrm{~km}$ buffer area positively correlated with bird species richness and diversity. In addition, habitat fragmentation also significantly negatively affected bird species richness and diversity. Our results emphasized that landscape attributes in surrounding areas are also important determinants affecting bird species richness and diversity, offering several practical implications for urban biodiversity maintenance and eco-friendly urban planning. To begin with, water bodies should be retained or planned when designing and constructing a new urban area since urban water bodies would support urban adaptive waterbirds [37]. In addition, larger urban green spaces, such as urban forests and lawns, should be planted as they can provide forage habitats, nesting sites, and movement corridors [38-40]. More importantly, as the surrounding landscape may intensively affect urban bird species richness, we highly suggest urban planners and policymakers consider urban areas as a whole when urban planning. This would be achieved by enlarging urban green spaces and planting more street trees to improve connectivity and reduce the edge effects created by fragmentation.

Supplementary Materials: The following are available online at https:/ /www.mdpi.com/article/10 $.3390 /$ su13105558/s1, Table S1: The checklist of bird species recorded from the surveyed 12 Universities, Nanjing.

Author Contributions: Conceptualization, Y.Z. (Yong Zhang), L.M., and B.C.; methodology, Y.Z. (Yong Zhang), C.J., S.C., Y.Z. (Yuanyuan Zhang), and H.S.; formal analysis, Y.Z. (Yong Zhang), C.J., and B.C.; investigation, Y.Z. (Yong Zhang), C.J., S.C., Y.Z. (Yuanyuan Zhang), and H.S.; resources, L.M.; data curation, Y.Z. (Yong Zhang), C.J., and B.C.; writing-original draft preparation, Y.Z. (Yong Zhang) and C.J;; writing - review and editing, S.C., Y.Z. (Yuanyuan Zhang), H.S., L.M., and B.C.; visualization, Y.Z. and C.J.; supervision, Y.Z. (Yong Zhang); project administration, L.M.; funding acquisition, Y.Z. (Yong Zhang) and L.M. All authors have read and agreed to the published version of the manuscript.

Funding: This study was supported by the Strategic Priority Research Program of the Chinese Academy of Sciences (Grant No. XDB31000000), Natural Science Foundation of Jiangsu Province (Grant No. BK20170922), and the National Natural Science Foundation of China (32071526).

Institutional Review Board Statement: Ethical review and approval were waived for this study, due to only non-experimental clinical veterinary practices were performed and no handling of animals related to research was carried out.

Informed Consent Statement: Not applicable. 
Data Availability Statement: The data presented in this study are available on request from the corresponding author.

Acknowledgments: We thank Zhiyong Li, Yu Xie, Yawen Liu, Min Wang, Jiaqi Shui, and Xu Qian for their assistance during the monthly bird survey.

Conflicts of Interest: The authors declare no conflict of interest.

\section{References}

1. Rounsevell, M.D.A.; Harfoot, M.; Harrison, P.A.; Newbold, T.; Gregory, R.D.; Mace, G.M. A biodiversity target based on species extinctions. Science 2020, 368, 1193-1195. [CrossRef]

2. Johnson, C.N.; Balmford, A.; Brook, B.W.; Buettel, J.C.; Galetti, M.; Lei, G.C.; Wilmshurst, J.M. Biodiversity losses and conservation responses in the Anthropocene. Science 2017, 356, 270-274. [CrossRef]

3. Ibanez-Alamo, J.D.; Rubio, E.; Benedetti, Y.; Morelli, F. Global loss of avian evolutionary uniqueness in urban areas. Glob. Chang. Biol. 2017, 23, 2990-2998. [CrossRef]

4. McDonald, R.I.; Mansur, A.V.; Ascensao, F.; Colbert, M.; Crossman, K.; Elmqvist, T.; Gonzalez, A.; Güneralp, B.; Haase, D.; Hamann, M.; et al. Research gaps in knowledge of the impact of urban growth on biodiversity. Nat. Sustain. 2020, 3, 16-24. [CrossRef]

5. Guneralp, B.; Seto, K.C. Futures of global urban expansion: Uncertainties and implications for biodiversity conservation. Environ. Res. Lett. 2013, 8, 014025. [CrossRef]

6. Yong, D.L.; Barton, P.S.; Okada, S.; Crane, M.; Lindenmayer, D.B. Birds as surrogates for mammals and reptiles: Are patterns of cross-taxonomic associations stable over time in a human-modified landscape? Ecol. Indic. 2016, 69, 152-164. [CrossRef]

7. Paker, Y.; Yom-Tov, Y.; Alon-Mozes, T.; Barnea, A. The effect of plant richness and urban garden structure on bird species richness, diversity and community structure. Landsc. Urban. Plan. 2014, 122, 186-195. [CrossRef]

8. Tzortzakaki, O.; Kati, V.; Kassara, C.; Tietze, D.T.; Giokas, S. Seasonal patterns of urban bird diversity in a Mediterranean coastal city: The positive role of open green spaces. Urban. Ecosyst. 2018, 21, 27-39. [CrossRef]

9. Plummer, K.E.; Gillings, S.; Siriwardena, G.M. Evaluating the potential for bird-habitat models to support biodiversity-friendly urban planning. J. Appl. Ecol. 2020, 57, 1902-1914. [CrossRef]

10. Yang, X.; Tan, X.; Chen, C.; Wang, Y. The influence of urban park characteristics on bird diversity in Nanjing, China. Avian Res. 2020, 11, 1-9. [CrossRef]

11. Zhang, W.J.; Liang, C.X.; Liu, J.; Si, X.F.; Feng, G. Species richness, phylogenetic and functional structure of bird communities in Chinese university campuses are associated with divergent variables. Urban. Ecosyst. 2018, 21, 1213-1225. [CrossRef]

12. Chen, S.Q.; Lu, M.Y.; Tan, H.W.; Luo, X.Y.; Ge, J. Assessing sustainability on Chinese university campuses: Development of a campus sustainability evaluation system and its application with a case study. J. Build. Eng. 2019, $24,100747$.

13. Gao, Y.; Shahab, S.; Ahmadpoor, N. Morphology of urban villages in China: A case study of Dayuan Village in Guangzhou. Urban. Sci. 2020, 4, 23. [CrossRef]

14. Boeing, G. The morphology and circuity of walkable and drivable street networks. In The Mathematics of Urban Morphology; Birkhäuser: Cham, Switzerland, 2019; pp. 271-287.

15. Bibby, C.J. Bird Census Techniques, 2nd ed.; Academic: San Diego, CA, USA, 2000.

16. van Heezik, Y.; Smyth, A.; Mathieu, R. Diversity of native and exotic birds across an urban gradient in a New Zealand city. Landsc. Urban. Plan. 2008, 87, 223-232. [CrossRef]

17. Dallimer, M.; Rouquette, J.R.; Skinner, A.M.J.; Armsworth, P.R.; Maltby, L.M.; Warren, P.H.; Gaston, K.J. Contrasting patterns in species richness of birds, butterflies and plants along riparian corridors in an urban landscape. Divers. Distrib. 2012, 18, 742-753. [CrossRef]

18. Suttidate, N.; Hobi, M.L.; Pidgeon, A.M.; Round, P.D.; Coops, N.C.; Helmers, D.P.; Keuler, N.S.; Dubinin, M.; Bateman, B.L.; Radeloff, V.C. Tropical bird species richness is strongly associated with patterns of primary productivity captured by the Dynamic Habitat Indices. Remote Sens. Environ. 2019, 232, 111306. [CrossRef]

19. Leveau, L.M.; Isla, F.I.; Bellocq, M.I. Predicting the seasonal dynamics of bird communities along an urban-rural gradient using NDVI. Landsc. Urban. Plan. 2018, 177, 103-113. [CrossRef]

20. MacArthur, R.H.; Wilson, E.O. The Theory of Island Biogeography; Princeton University Press: Princeton, NJ, USA, 1967.

21. Liu, J.; Bai, H.T.; Ma, H.Y.; Feng, G. Bird diversity in Chinese urban parks was more associated with natural factors than anthropogenic factors. Urban. Urban. Gree 2019, 43, 126358. [CrossRef]

22. Callaghan, C.T.; Major, R.E.; Lyons, M.B.; Martin, J.M.; Kingsford, R.T. The effects of local and landscape habitat attributes on bird diversity in urban greenspaces. Ecosphere 2018, 9, e02347. [CrossRef]

23. Villasenor, N.R.; Escobar, M.A.H. Cemeteries and biodiversity conservation in cities: How do landscape and patch-level attributes influence bird diversity in urban park cemeteries? Urban. Ecosyst. 2019, 22, 1037-1046. [CrossRef]

24. Villasenor, N.R.; Driscoll, D.A.; Gibbons, P.; Calhoun, A.J.K.; Lindenmayer, D.B. The relative importance of aquatic and terrestrial variables for frogs in an urbanizing landscape: Key insights for sustainable urban development. Landsc. Urban. Plan. 2017, 157, 26-35. [CrossRef] 
25. Jokimaki, J.; Suhonen, J.; Kaisanlahti-Jokimaki, M.L. Urban core areas are important for species conservation: A European-level analysis of breeding bird species. Landsc. Urban. Plan. 2018, 178, 73-81. [CrossRef]

26. Amaya-Espinel, J.D.; Hostetler, M.; Henriquez, C.; Bonacic, C. The influence of building density on Neotropical bird communities found in small urban parks. Landsc. Urban. Plan. 2019, 190, 103578. [CrossRef]

27. Andersson, E.; Colding, J. Understanding how built urban form influences biodiversity. Urban. Urban. Gree 2014, 13, 221-226. [CrossRef]

28. Ikin, K.; Beaty, R.M.; Lindenmayer, D.B.; Knight, E.; Fischer, J.; Manning, A.D. Pocket parks in a compact city: How do birds respond to increasing residential density? Landsc. Ecol. 2013, 28, 45-56. [CrossRef]

29. Fletcher, R.J.; Didham, R.K.; Banks-Leite, C.; Barlow, J.; Ewers, R.M.; Rosindell, J.; Holt, R.D.; Gonzalez, A.; Pardini, R.; Damschen, E.I.; et al. Is habitat fragmentation good for biodiversity? Biol. Conserv. 2018, 226, 9-15. [CrossRef]

30. Johnson, C.D.; Evans, D.; Jones, D. Birds and Roads: Reduced Transit for Smaller Species over Roads within an Urban Environment. Front. Ecol. Evol. 2017, 5, 36. [CrossRef]

31. Nol, E.; Francis, C.M.; Burke, D.M. Using distance from putative source woodlots to predict occurrence of forest birds in putative sinks. Conserv. Biol. 2005, 19, 836-844. [CrossRef]

32. Korfanta, N.M.; Newmark, W.D.; Kauffman, M.J. Long-term demographic consequences of habitat fragmentation to a tropical understory bird community. Ecology 2012, 93, 2548-2559. [CrossRef]

33. Shanahan, D.F.; Miller, C.; Possingham, H.P.; Fuller, R.A. The influence of patch area and connectivity on avian communities in urban revegetation. Biol. Conserv. 2011, 144, 722-729. [CrossRef]

34. Uezu, A.; Metzger, J.P.; Vielliard, J.M.E. Effects of structural and functional connectivity and patch size on the abundance of seven Atlantic Forest bird species. Biol. Conserv. 2005, 123, 507-519. [CrossRef]

35. Brondizio, E.S.; O’Brien, K.; Bai, X.M.; Biermann, F.; Steffen, W.; Berkhout, F.; Cudennec, C.; Lemos, M.C.; Wolfe, A.; Palma-Oliveira, J.; et al. Re-conceptualizing the Anthropocene: A call for collaboration. Glob. Environ. Chang. 2016, 39, 318-327. [CrossRef]

36. Melles, S.; Glenn, S.; Martin, K. Urban bird diversity and landscape complexity: Species-environment associations along a multiscale habitat gradient. Conserv. Ecol. 2003, 7, 5. [CrossRef]

37. Murray, C.G.; Kasel, S.; Loyn, R.H.; Hepworth, G.; Hamilton, A.J. Waterbird use of artificial wetlands in an Australian urban landscape. Hydrobiologia 2013, 716, 131-146. [CrossRef]

38. Kontsiotis, V.J.; Valsamidis, E.; Liordos, V. Organization and differentiation of breeding bird communities across a forested to urban landscape. Urban. Urban. Gree 2019, 38, 242-250. [CrossRef]

39. Grafius, D.R.; Corstanje, R.; Siriwardena, G.M.; Plummer, K.E.; Harris, J.A. A bird's eye view: Using circuit theory to study urban landscape connectivity for birds. Landsc. Ecol. 2017, 32, 1771-1787. [CrossRef]

40. Aronson, M.F.J; Lepczyk, C.A.; Evans, K.L.; Goddard, M.A.; Lerman, S.B.; MacIvor, J.S.; Nilon, C.H.; Vargo, T. Biodiversity in the city: Key challenges for urban green space management. Front. Ecol. Environ. 2017, 15, 189-196. [CrossRef] 